\title{
Reproductive biology of the flatback turtle Natator depressus in Western Australia
}

\author{
Kellie L. Pendoley*, Catherine D. Bell, Rebecca McCracken, Kirsten R. Ball, \\ Jarrad Sherborne, Jessica E. Oates, Patrick Becker, Anna Vitenbergs, \\ Paul A. Whittock
}

Pendoley Environmental Pty Ltd, 2/1 Aldous Place, Booragoon, WA 6154, Australia

\begin{abstract}
In contrast to the circumglobal nesting distributions and well-described reproductive biology of most marine turtle species, all known records of flatback turtle Natator depressus nesting have occurred within Australia and are relatively underreported; the species is listed as 'Data Deficient' by the International Union for the Conservation of Nature (IUCN). We report important baseline data on the breeding biology of flatback turtles at 3 rookeries in the Pilbara region of Western Australia, an area subject to increasing coastal development due to rapid expansion of the resources sector. Barrow Island and Mundabullangana support substantial reproductive populations; over the 6 season sampling period from 2005/06 to 2010/11, 4000 and 3500 turtles were tagged at each location, respectively. Over 2 seasons of monitoring in 2009/10 and 2011/12 at Cemetery Beach, a smaller rookery in Port Hedland, 350 flatback turtles were tagged. We detected variation in parameters of reproductive biology between island and mainland rookeries. Mean remigration interval at Barrow Island (1.9 yr) was significantly shorter than at mainland Mundabullangana (2.2 yr) and may reflect differences in location and characteristics of remote foraging habitats in turtles returning to mainland versus offshore rookeries. Clutch size was similar ( 47 eggs) among rookeries and smaller than mean clutch sizes recorded for all other Australian flatback rookeries ( 53 eggs). Hatching success at Barrow Island $(83.4 \%)$ was within the reported range for the species; however, at Mundabullangana and Cemetery Beach $(68.2 \%$ and $57.3 \%$, respectively) these values were the lowest published to date for this species and may be attributable to higher temperatures at mainland rookeries.
\end{abstract}

KEY WORDS: Flatback turtle - Western Australia · Resources industry · Population monitoring • IUCN Red Listing

- Resale or republication not permitted without written consent of the publisher

\section{INTRODUCTION}

The flatback turtle Natator depressus is an endemic Australian species; populations are distributed throughout continental shelf waters of northern Australia, extending from the Pilbara region of Western Australia, northwards around the Northern Territory and into Queensland waters (Bustard et al. 1975, Limpus 1971, 2009, Limpus et al. 1981, 1983, 1988, Parmenter \& Limpus 1995) (Fig. 1). Though currently listed as 'Data Deficient' by the International Union for the Conservation of Nature (IUCN), (IUCN 2010) this species is listed nationally as 'endangered' under the Environmental Protection of Biodiversity and Conservation (EPBC) Act (1999). Four genetic stocks are currently recognized: Western Australia, Northern Territory, Gulf of Carpentaria and Eastern Australia (Dutton et al. 2002; Fig.1), which are further combined as 2 distinct Regional Management Units (RMUs) by the IUCN Marine Turtle Specialist Group (Wallace et al. 2010). To date, the only long-term studies on the breeding biology of flatback turtles 


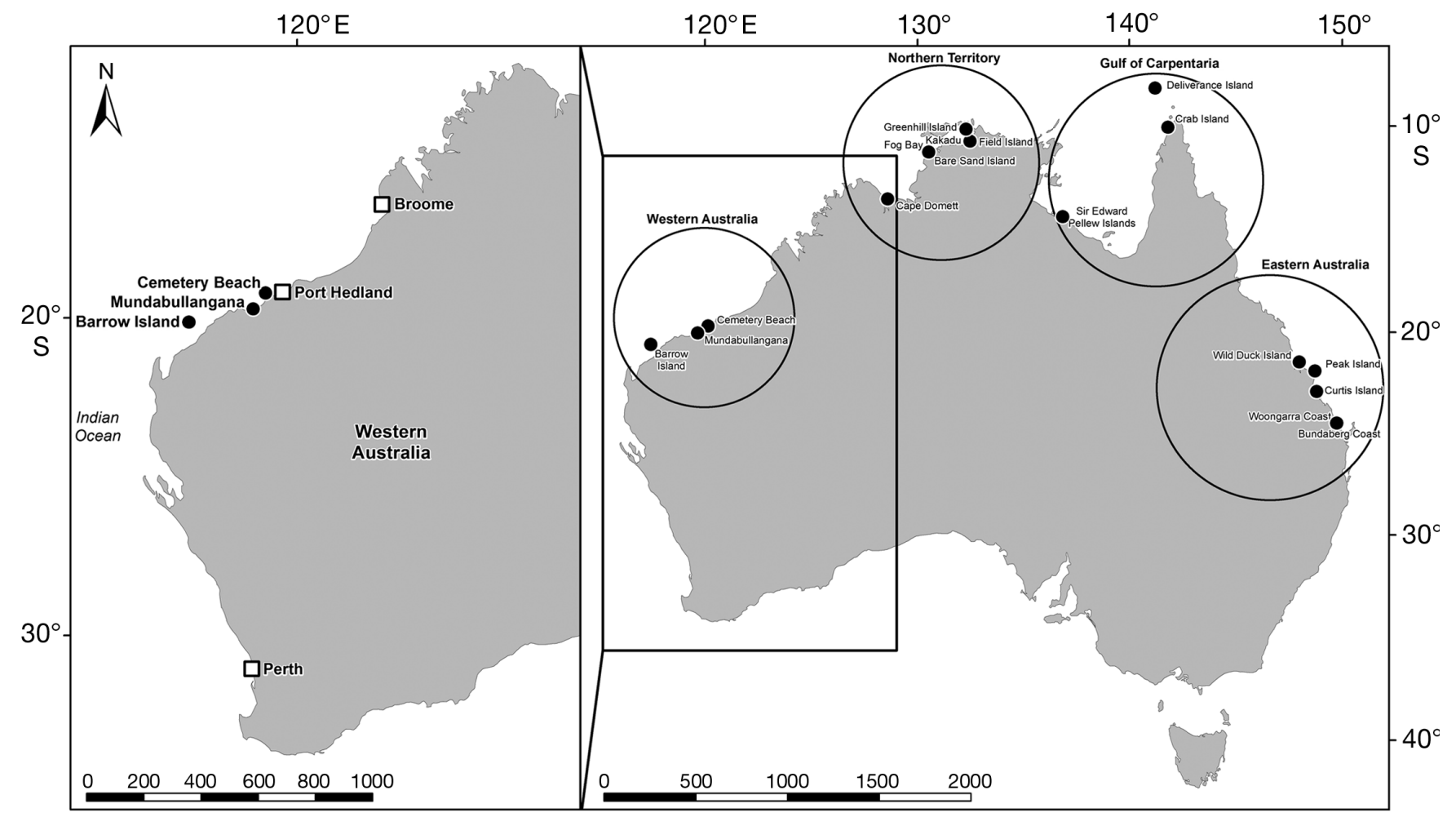

Fig. 1. Location of the Barrow Island, Mundabullangana and Cemetery Beach flatback turtle Natator depressus rookeries in the Pilbara region, Western Australia (left panel), and boundaries of the 4 currently recognized genetic stocks for this species "(black circles;right panel)"

have been confined to Queensland (Limpus et al. 1981, 1983, 1984, Parmenter \& Limpus 1995), with little published information on flatback populations of Western Australia (but see Whiting et al. 2008).

Threats to marine turtles in Western Australia include coastal and offshore oil and gas exploration, light pollution from offshore and onshore lighting and gas flares, direct loss of habitat due to dredging and construction, accidental spillage of petroleum products, and physical disturbance from rapidly increasing human presence in the region (DEC 2007). Flatback turtle conservation thus features prominently in mitigation plans and impact assessments prepared by the rapidly expanding resources sector in this State. The current paucity of data regarding this species is a significant obstacle to conservation management in the region.

Here, we present the first comprehensive account of the reproductive biology of the flatback turtle in Western Australia. We report on the results of systematic capture-mark-recapture and incubation success monitoring programs and provide data on primary parameters of individual and population status including nesting female abundance, remigration and internesting intervals, clutch size and hatching success rates, and compare these parameters to other flatback turtle rookeries across Australia. Our results establish a baseline to properly assess the magnitude of contemporary and potential future threats and provide targets for effective management strategies in Western Australia.

\section{MATERIALS AND METHODS}

\section{Study sites}

The flatback turtle reproductive season spans the end of the calendar year and in Western Australia extends from October through to February, with variations in peak nesting periods among locations. We focused our monitoring efforts at 3 rookeries located in the Pilbara region of Western Australia (Fig. 1). Barrow Island (Barrow) lies $60 \mathrm{~km}$ off the mainland coast and has 7 primary flatback nesting beaches on the east coast of the island, facing the mainland. The beaches are between 500 to $1100 \mathrm{~m}$ long and 10 to $15 \mathrm{~m}$ wide (Pendoley 2005), and are all low energy beaches bounded by rocky headlands at each end. A large-scale natural gas facility is under construction on the east coast of the island situated among the nesting beaches. Mundabullangana (Munda) is $60 \mathrm{~km}$ southwest of Port Hedland (Fig. 1) and is used as a reference site for Barrow to assess potential impacts of 
construction and operation of the gas facility. The primary nesting site is Cowrie Beach, a $3.3 \mathrm{~km}$ long, narrow, low energy beach bounded by a mangrove creek to the northeast and a rocky headland to the southwest. The third rookery is at Cemetery Beach, which is $1 \mathrm{~km}$ long and is the main town beach for Port Hedland and the site of a large port expansion project.

\section{Monitoring duration and effort}

The Western Australian Department of Parks and Wildlife (DPaW) conducted flatback turtle flipper tagging on an ad hoc basis at Barrow from the 1984/85 to the 2004/05 season and for approximately 2 wk during the peak nesting season at Munda from $1992 / 93$ to 2004/05. Since 2005/06 at Barrow and Munda, and from 2009/10 to 2011/12 at Cemetery Beach, systematic monitoring programs have been undertaken by Pendoley Environmental Pty Ltd.

Monitoring was conducted for 2 to $3 \mathrm{~h}$ on either side of high tide in the late afternoon, early morning or night-time during the known peak nesting period at each location to maximize interaction with the highest number of nesting females. Six beaches at Barrow were surveyed in each monitoring season, except for 2005/06 when only 4 were monitored. Monitoring techniques were consistent at all locations; effort per beach was consistent at Barrow and Cemetery Beach and comprised 2 individuals (taggers) per beach on each survey night. Monitoring at Munda covered $2 \mathrm{~km}$ of the $3.3 \mathrm{~km}$ beach, and survey effort ranged from 2 (2006/07 and 2007/08) to 6 (2009/10 to 2011/12) taggers per survey night. Survey duration in some seasons was constrained by cyclonic events that prohibited access to beaches. Due to inter-annual variation in spatial and temporal distribution of monitoring effort across rookeries, we present data with regard to overall abundance as a minimum number.

\section{Capture-mark-recapture}

Nesting turtles were tagged with titanium flipper tags (Stockbrands) through the axial scale of both front flippers (Limpus 1992). Flatback turtles have soft skin and suffer high rates of flipper tag loss (Limpus et al. 1984, Parmenter 1993). Consequently, after 2009/10, all animals were implanted with passive integrated transponder (PIT) tags (Stockbrands) in the left shoulder, and flipper tagging was reduced to 1 tag in the left flipper. Turtles were systematically examined for flipper tag loss scars from 2008/09 to distinguish returning (but unidentifiable) nesting females from new recruits. Prior to 2010/11, all turtles encountered were tagged at any time, except during oviposition. After 2010/11, turtles were only tagged following completion of oviposition. If they did not lay, they were not tagged, as this was found to deter nesting, forcing turtles to leave the nesting beach and return another time/night, thus distorting data regarding the length of the 'internesting period' (period of time between successive clutches) and confounding findings of additional and often concurrent programs relying on track counts.

\section{Remigration and internesting intervals}

Remigration interval was calculated as the number of years between successive breeding seasons for individual females (Schauble et al. 2006). Internesting interval was calculated as the number of days from completion of oviposition to the next observed emergence onto the beach, successful or otherwise (Limpus et al. 1984). Where multiple observations were made of an animal in each season a mean internesting interval was determined for each animal in each year to avoid issues associated with pseudoreplication.

\section{Egg and hatchling morphology}

Egg mass $( \pm 0.01 \mathrm{~g}$ ) was measured using an electronic balance (Champion) and egg diameter $( \pm$ $1 \mathrm{~mm})$ was measured using analogue calipers (Vernier). Hatchling mass ( $\pm 1 \mathrm{~g}$ ) was measured using a spring balance (Pesola), and straight carapace length (SCL) ( $\pm 1 \mathrm{~mm}$ ) was measured using either digital or analogue calipers.

\section{Clutch selection and assessment}

Clutches were randomly selected and marked in situ at oviposition over a 2 -wk period in December at Barrow from 2006/07 to 2011/12 and at Munda and Cemetery Beach from 2009/10 to 2011/12. Additional clutches were sampled at Barrow in January 2011. Data loggers with an accuracy of $0.47^{\circ} \mathrm{C}$ and a resolution of $0.1^{\circ} \mathrm{C}$ (Tinytag TGP-4017 or Hobotemp UA001-08) were calibrated where possible and recorded the temperature of a subset of marked clutches every 30 min during incubation.

Where possible, clutches were monitored daily for signs of hatchling emergence beginning 37 to $39 \mathrm{~d}$ 
after oviposition and excavated either $5 \mathrm{~d}$ after the first emergence of hatchlings, or $>3 \mathrm{~d}$ after last emergence, whichever was longer (Shigenaka 2003). Alternatively, hatch date was inferred from temperature profiles provided by loggers placed in clutches.

Clutch contents were described as empty eggshells (>50\% intact), live hatchlings, dead hatchlings, and eggs with either no discernible embryo or partially or fully developed embryos (Shigenaka 2003). Hatching success was calculated as the percentage of the clutch that hatched, evidenced by empty eggshells (Miller 1999). Due to cyclonic activity restricting access to some beaches, in some seasons emergence success could not be accurately assessed and these data have been excluded. Clutch size (number of eggs) and clutch depth were recorded (mm). Clutch depth (mm) was measured from the sand surface to the bottom of the clutch using a fiberglass tape measure ( $\pm 1 \mathrm{~mm})$.

\section{Data analysis}

Tagging data are maintained in the Western Australian Department of Environment and Conservation Marine Turtle Research and Monitoring Database (WAMTRAM) v1.1.32. and are presented below as mean \pm standard deviation, range and sample size (n) where relevant, with full details provided in Tables 1 to 5 where not provided in text. Statistical analyses were performed using XLSTAT (Addinsoft, 2010), Analyise-It 2.04 (Analyse-it Software, 2007), and R (Ihaka \& Gentleman 1996). A generalized linear mixed effects modelling approach using individual turtles as a random effect to account for pseudoreplication was fitted using the lme4 package in $\mathrm{R}$ to detect differences in remigration and internesting intervals between Barrow and Munda only. At Cemetery Beach where fewer seasons of data were available, remigration intervals were calculated as the mean number of years between resightings of each individual, and these data were also treated for pseudoreplication. All other parameters were assessed for distribution normality and either ANOVA or Kruskal-Wallis tests used to detect statistically significant differences between rookeries.

\section{RESULTS}

\section{Nester abundance and remigration}

Between 2005/06 and 2011/12, 3976 tagged individual female flatback turtles were observed at Barrow and over all survey seasons, the mean number of animals encountered per night was $60.6 \pm 16.7$. At Munda, in the same period, 2542 individuals were observed and the mean number of animals encountered per night was $37.4 \pm 14.5$, ranging from $19.8 \pm$ 9.2 in 2006/07 to $61.3 \pm 19.0$ in 2008/09. At Cemetery Beach, between 2009/10 and 2011/12, 361 individual turtles were observed, and the mean number of animals encountered per night was $7.1 \pm 2.2$, ranging from $5.3 \pm 7.0$ in $2010 / 11$ to $9.5 \pm 9.9$ in $2009 / 10$ (Table 1).

Annual nester abundance and proportion (\%) of new and remigrant females are shown in Table 2. The proportion of tagged turtles returning in each reproductive season is presented in Table 3. There was limited inter- and intra-seasonal interchange of nesters among monitored mainland locations, i.e. Munda and Cemetery Beach (5 individuals were observed at both locations in 2009/10,

Table 1. Natator depressus. Monitoring effort and observations of nesting flatback turtles at Barrow Island (6 beaches, except 2005/06 when only 4 beaches were monitored), Mundabullangana and Cemetery Beach rookeries in Western Australia from 2005/06 to 2001/12. Monitoring effort is shown as numbers of monitoring nights per season and numbers of taggers per beach in each season

\begin{tabular}{|c|c|c|c|c|c|}
\hline \multirow[t]{2}{*}{ Location } & \multicolumn{2}{|c|}{ Monitoring effort } & \multicolumn{3}{|c|}{ No. of observations per nigh } \\
\hline & $\begin{array}{l}\text { No. of } \\
\text { nights }\end{array}$ & $\begin{array}{l}\text { No. of } \\
\text { taggers }\end{array}$ & Mean & $\mathrm{SD}$ & Range \\
\hline \multicolumn{6}{|c|}{ Barrow Island } \\
\hline $2005 / 06$ & 52 & 8 & 33.6 & 27.5 & $1-116$ \\
\hline $2006 / 07$ & 57 & 12 & 65.1 & 49.0 & $1-163$ \\
\hline $2007 / 08$ & 51 & 12 & 85.0 & 46.4 & $3-203$ \\
\hline 2008/09 & 52 & 12 & 65.5 & 38.4 & $6-188$ \\
\hline $2009 / 10$ & 54 & 12 & 72.2 & 51.5 & $1-203$ \\
\hline $2010 / 11$ & 33 & 12 & 48.9 & 46.0 & $1-160$ \\
\hline $2011 / 12$ & 58 & 12 & 54.1 & 40.0 & $1-151$ \\
\hline \multicolumn{6}{|c|}{ Mundabullangana } \\
\hline $2005 / 06$ & 14 & 4 & 45.1 & 25.7 & $4-94$ \\
\hline $2006 / 07$ & 10 & 2 & 19.8 & 9.2 & $4-34$ \\
\hline $2007 / 08$ & 13 & 2 & 23.7 & 12.7 & $2-40$ \\
\hline $2008 / 09$ & 16 & 4 & 61.3 & 19.0 & $11-90$ \\
\hline $2009 / 10$ & 50 & 6 & 42.0 & 34.4 & $1-113$ \\
\hline $2010 / 11$ & 37 & 6 & 42.4 & 23.9 & $5-88$ \\
\hline $2011 / 12$ & 57 & 6 & 27.6 & 17.1 & $1-75$ \\
\hline \multicolumn{6}{|c|}{ Cemetery Beach } \\
\hline $2009 / 10$ & 56 & 2 & 9.5 & 9.9 & $0-48$ \\
\hline 2010/11 & 57 & 2 & 5.3 & 7.0 & $0-38$ \\
\hline $2011 / 12$ & 54 & 2 & 6.5 & 4.5 & $1-18$ \\
\hline
\end{tabular}


Table 2. Natator depressus. Numbers of total nesting flatback turtles observed at Barrow Island, Mundabullangana and Cemetery Beach rookeries in each monitoring season. 'New': previously untagged female turtles; 'remigrant': previously tagged females, identifiable by tag presence or by scar where tag had been lost. Females with tag scars were noted from 2008/09 onwards; prior to this season, these females were included as 'new turtles' because tag scars were not systematically recorded. '\% remigrant': proportion of previously tagged animals encountered in each season

\begin{tabular}{|lcccc|}
\hline \multirow{2}{*}{ Location } & \multicolumn{4}{c|}{ Turtle observations } \\
\cline { 2 - 5 } & New & Remigrant & Total & \% remigrant \\
\hline Barrow Island & & & & \\
$2005 / 06$ & 849 & 46 & 895 & 5 \\
$2006 / 07$ & 1067 & 296 & 1363 & 22 \\
$2007 / 08$ & 779 & 827 & 1606 & 51 \\
$2008 / 09$ & 364 & 1054 & 1418 & 74 \\
$2009 / 10$ & 275 & 1174 & 1449 & 81 \\
$2010 / 11$ & 102 & 732 & 834 & 87 \\
$2011 / 12$ & 193 & 969 & 1162 & 79 \\
Mundabullangana & & & \\
$2005 / 06$ & 303 & 207 & 510 & 41 \\
$2006 / 07$ & 123 & 68 & 191 & 36 \\
$2007 / 08$ & 122 & 129 & 251 & 51 \\
$2008 / 09$ & 274 & 337 & 611 & 55 \\
$2009 / 10$ & 379 & 657 & 1036 & 63 \\
$2010 / 11$ & 201 & 685 & 886 & 77 \\
$2011 / 12$ & 171 & 640 & 811 & 79 \\
Cemetery Beach & & & & \\
$2009 / 10$ & 182 & 6 & 188 & 87 \\
$2010 / 11$ & 116 & 50 & 166 & 30 \\
$2011 / 12$ & 51 & 97 & 148 & 66 \\
\hline
\end{tabular}

2 in 2010/11 and 3 in 2011/12). No individuals tagged at Barrow were observed at either mainland rookery.

Mean remigration interval (yr) of turtles nesting at Munda was $2.2 \pm 1.6$, significantly longer than at Barrow (1.9 \pm 0.8$)(\mathrm{df}=1, \mathrm{p}<0.001)$. Limited

Table 3. Natator depressus. Remigration intervals of identifiable remigrant females (i.e. with tags) in the most recent monitoring season at each location (2011/12). Data represent 6 survey seasons at Barrow and Mundabullangana and 2 at Cemetery Beach and are presented as: (yr), remigration interval; $(\mathrm{n})$, number of turtles observed; $(\%)$, proportion of total remigrants

\begin{tabular}{|c|c|c|c|c|c|c|}
\hline \multirow{2}{*}{$\begin{array}{l}\text { Remigration } \\
\text { interval (yr) }\end{array}$} & \multicolumn{2}{|c|}{ Barrow Island } & \multicolumn{2}{|c|}{ Mundabullangana } & \multicolumn{2}{|c|}{ Cemetery Beach } \\
\hline & $\mathrm{n}$ & $\%$ & $\mathrm{n}$ & $\%$ & $\mathrm{n}$ & $\%$ \\
\hline 1 & 120 & 13.2 & 208 & 38.2 & 38 & 40.4 \\
\hline 2 & 587 & 64.7 & 285 & 52.4 & 56 & 59.6 \\
\hline 3 & 132 & 14.6 & 33 & 6.1 & - & - \\
\hline 4 & 48 & 5.3 & 9 & 1.7 & - & - \\
\hline 5 & 15 & 1.7 & 4 & 0.7 & - & - \\
\hline 6 & 5 & 0.6 & 5 & 0.9 & - & - \\
\hline Total & 907 & 100 & 544 & 100 & 94 & 100 \\
\hline
\end{tabular}

data from Cemetery Beach indicate that the mean remigration interval was $1.6 \pm 0.5$ (Table 4 )

Mean internesting interval (d) of mainland nesters at Munda $(13.0 \pm 3.3)$ and Cemetery Beach (12.2 \pm 1.5) was significantly shorter than that of island nesters at Barrow $(14.1 \pm 2.2)(\mathrm{df}=2, \mathrm{p}<0.0001)$ (Tables 4 \& 5).

\section{Reproductive output}

Mean clutch size (number of eggs) was $46.6 \pm 10.3$ (6 to 781), $46.6 \pm 8.6$ (16 to 64 ) and $46.6 \pm 9.4$ (8 to 67 ) at Barrow, Munda and Cemetery Beach, respectively (Table 4 ) and was similar across rookeries $(p \geq 0.05)$ with no significant difference in mean clutch size among seasons at each location ( $p \geq 0.05)$.

Mean hatch success (\%) at Barrow Island was 83.4 \pm 19.3 , significantly higher than at Munda (68.2 \pm 23.9) and Cemetery Beach $(57.3 \pm 29.6)(\mathrm{p}<0.0001)$ (Tables 4 \& 5).

Mean nest bottom depth $(\mathrm{cm})$ was similar at all 3 rookeries $(p=0.042)$, but nests at Munda $(65.9 \pm 19.3$, 29.8 to $120, \mathrm{n}=134$ ) were slightly shallower than at Barrow $(71.1 \pm 9.5,47$ to $110, \mathrm{n}=253)$ and Cemetery Beach $(70.4 \pm 11.1,50$ to $110, \mathrm{n}=68$ ) (Tables $4 \& 5)$.

Mean incubation period (d) at Barrow (47.2 \pm 2.4 ) was significantly longer than at Cemetery Beach $(46.0 \pm 0.5)$ and Munda (46.1 \pm 0.6$)$ for seasons in which these data were available $(\mathrm{p}=0.0063)$ (Tables 4 \& 5).

Mean clutch temperature $\left({ }^{\circ} \mathrm{C}\right) \quad(2010 / 11$ and $2011 / 12)$ at Cemetery Beach $(33.8 \pm 0.6)$ was significantly higher than on beaches at Munda (33.1 \pm 0.3$)$ and Barrow Island $(31.7 \pm 0.6)(F=7.43, \mathrm{p}=0.001$; Table 4) during the same period (Tables 4 \& 5). Mean maximum daily air temperature $\left({ }^{\circ} \mathrm{C}\right)$ during the same period (1 Dec to 28 Feb) was $35.2 \pm 2.8$ (27.4 to $43.0, \mathrm{n}=180$ ) at Port Hedland, which is the nearest proxy for Cemetery Beach and Munda, significantly higher than at Barrow $(33.0 \pm 2.5,28.6$ to $39.2, \mathrm{n}=$ 157) $(\mathrm{p}=0.000)$.

\section{Hatchling and egg morphometrics}

Egg mass (g) varied among rookeries; mean egg mass at Munda was $55.0 \pm 11.1$ (24.4 to $74.0, n=203$ ), lighter than eggs at Cemetery Beach $(67.8 \pm 12.3,46.0$ to 97.9 , $\mathrm{n}=95)$, which in turn were lighter than at Barrow $(72.1 \pm 6.68,54.6$ to $86.7, \mathrm{n}=142)$ 
Table 4. Natator depressus. Summary of biological data collected at Barrow Island, Mundabullangana and Cemetery Beach rookeries. ' $n$ ' represents the number of remigration or internesting intervals or the number of clutches assessed (for clutch size, hatch success, emergence success, incubation duration, clutch depth, clutch temperature)

\begin{tabular}{|c|c|c|c|c|c|}
\hline & Mean & $\mathrm{SD}$ & Range & $\mathrm{n}$ & Monitoring period \\
\hline \multicolumn{6}{|l|}{ Barrow Island } \\
\hline Remigration interval (yr) & 1.9 & 0.8 & $1-7$ & 2181 & $2005 / 06-2011 / 12$ \\
\hline Internesting interval (d) & 14.1 & 2.2 & $7-22$ & 3646 & $2005 / 06-2011 / 12$ \\
\hline Clutch size (no. of eggs) & 46.6 & 10.3 & $6-78$ & 311 & $2005 / 06-2011 / 12$ \\
\hline Hatch success (\%) & 83.4 & 19.3 & $2-100$ & 254 & $2006 / 07-2011 / 12$ \\
\hline Emergence success (\%) & 78.8 & 22.6 & $2-100$ & 228 & $2007 / 08-2011 / 12$ \\
\hline Incubation duration (d) & 47.2 & 2.4 & $37-54$ & 114 & $2007 / 08-2011 / 12$ \\
\hline Clutch depth $(\mathrm{cm})$ & 71.1 & 9.5 & $47-110$ & 253 & $2006 / 07-2011 / 12$ \\
\hline Clutch temperature $\left({ }^{\circ} \mathrm{C}\right)$ & 31.7 & 0.6 & $28-36$ & 53 & $2010 / 11-2011 / 12$ \\
\hline \multicolumn{6}{|l|}{ Mundabullangana } \\
\hline Remigration interval (yr) & 2.2 & 1.6 & $1-10$ & 1007 & $2005 / 06-2011 / 12$ \\
\hline Internesting interval (d) & 13.0 & 3.3 & $9-22$ & 1260 & $2005 / 06-2011 / 12$ \\
\hline Clutch size (no. of eggs) & 46.6 & 8.6 & $17-64$ & 140 & $2009 / 10-2011 / 12$ \\
\hline Hatch success $(\%)$ & 68.2 & 23.9 & $3-97$ & 134 & $2009 / 10-2010 / 12$ \\
\hline Emergence success (\%) & 58.3 & 29.2 & $0-97$ & 124 & 2009/10-2010/12 \\
\hline Incubation duration (d) & 46.1 & 0.6 & $39-48$ & 43 & $2009 / 10 \& 2011 / 12$ \\
\hline Clutch depth $(\mathrm{cm})$ & 65.9 & 19.3 & $30-120$ & 134 & $2009 / 10-2011 / 12$ \\
\hline Clutch temperature $\left({ }^{\circ} \mathrm{C}\right)$ & 33.1 & 0.3 & $31-37$ & 41 & $2010 / 11-2011 / 12$ \\
\hline \multicolumn{6}{|l|}{ Cemetery Beach } \\
\hline Remigration interval (yr) & 1.6 & 0.5 & $1-2$ & 94 & $2010 / 11-2011 / 12^{\mathrm{a}}$ \\
\hline Internesting interval (d) & 12.2 & 1.5 & $7-18$ & 240 & $2009 / 10-2011 / 12$ \\
\hline Clutch size (no. of eggs) & 46.6 & 9.4 & $8-67$ & 83 & $2009 / 10-2010 / 12$ \\
\hline Hatch success $(\%)$ & 57.3 & 29.6 & $2-97$ & 62 & $2010 / 11-2011 / 12$ \\
\hline Emergence success (\%) & 48.0 & 30.7 & $2-97$ & 59 & 2010/11-2011/12 \\
\hline Incubation duration (d) & 46.0 & 0.5 & $40-50$ & 36 & 2010/11-2011/12 \\
\hline Clutch depth $(\mathrm{cm})$ & 70.4 & 11.1 & $50-110$ & 68 & $2010 / 11-2011 / 12$ \\
\hline Clutch temperature $\left({ }^{\circ} \mathrm{C}\right)$ & 33.8 & 0.6 & $28-35$ & 54 & $2010 / 11-2011 / 12$ \\
\hline
\end{tabular}

Table 5. Natator depressus. Statistical significance of pairwise comparisons of key parameters of reproductive biology among 3 flatback turtle rookeries in the Pilbara region of Western Australia. N/A: not applicable; BWI: Barrow; MDA: Mundabullangana; CB: Cemetery Beach; SCL: straight carapace length; $\leftrightarrow$ : No significant difference between pairs; $\uparrow(\downarrow)$ : parameter value for the first named of the pair is significantly higher (lower) than for the second. Statistical significance was assigned to values $\leq 0.05$

\begin{tabular}{|c|c|c|c|c|c|c|}
\hline Parameter & $\begin{array}{c}\text { BWI } \\
\text { vs. MDA }\end{array}$ & $\mathrm{p}$ & $\begin{array}{c}\text { BWI } \\
\text { vs. CB }\end{array}$ & $\mathrm{p}$ & $\begin{array}{c}\text { MDA } \\
\text { vs. CB }\end{array}$ & $\mathrm{p}$ \\
\hline Clutch size (no. of eggs) & $\leftrightarrow$ & $>0.05$ & $\leftrightarrow$ & $>0.05$ & $\leftrightarrow$ & $>0.05$ \\
\hline Hatch success (\%) & $\uparrow$ & $<0.0001$ & $\uparrow$ & $<0.0001$ & $\uparrow$ & $<0.01$ \\
\hline Emergence success (\%) & $\uparrow$ & $<0.0001$ & $\uparrow$ & $<0.0001$ & $\uparrow$ & $<0.0001$ \\
\hline Bottom nest depth (cm) & $\leftrightarrow$ & $>0.05$ & $\leftrightarrow$ & $>0.05$ & $\leftrightarrow$ & $>0.05$ \\
\hline Incubation period (d) & $\uparrow$ & $<0.05$ & $\uparrow$ & $<0.05$ & $\leftrightarrow$ & $>0.05$ \\
\hline Egg mass (g) & $\uparrow$ & $<0.0001$ & $\uparrow$ & $<0.0001$ & $\downarrow$ & $<0.0001$ \\
\hline Egg diameter (mm) & $\uparrow$ & $<0.0001$ & $\uparrow$ & $<0.0001$ & $\uparrow$ & $<0.0001$ \\
\hline Hatchling SCL (mm) & $\leftrightarrow$ & $>0.05$ & $\leftrightarrow$ & $>0.05$ & $\leftrightarrow$ & $>0.05$ \\
\hline Hatchling mass ( $\mathrm{g}$ ) & $\downarrow$ & $<0.0001$ & $\leftrightarrow$ & $>0.05$ & $\uparrow$ & $<0.0001$ \\
\hline Remigration interval (yr) & $\downarrow$ & $<0.05$ & N/A & $\mathrm{N} / \mathrm{A}$ & N/A & N/A \\
\hline Internesting interval (d) & $\uparrow$ & $<0.0001$ & $\uparrow$ & $<0.0001$ & $\leftrightarrow$ & $>0.05$ \\
\hline
\end{tabular}

( $\mathrm{p}<0.0001)$. Similarly, egg diameter $(\mathrm{mm})$ varied among locations; eggs at Cemetery Beach (46.4 \pm $1.84,40.8$ to $52.0, \mathrm{n}=244$ ) were smaller than eggs at
Munda $(49.0 \pm 1.94,39.7$ to $52.6, \mathrm{n}$ $=276$ ), which were in turn smaller than those at Barrow $(51.1 \pm 2.0$, 46.1 to $57.1, \mathrm{n}=152)(\mathrm{p}<0.0001)$ (Tables 4 \& 5).

Mean hatchling SCL (mm) at Barrow was $57.5 \pm 2.9$ (50.1 to 63.2, $\mathrm{n}=118$ ), similar to Cemetery Beach $(57.7 \pm 2.2,53.1$ to 62.5, $\mathrm{n}=39$ ) and Munda (56.9 \pm $3.7,39.6$ to $69.8, \mathrm{n}=148)(\mathrm{p}>$ $0.05)$. The very slightly shorter hatchling lengths at Munda did, however, correspond with significantly lower hatchling mass compared to Barrow and Cemetery Beach $(p<0.0001)$. Mean hatchling mass $(\mathrm{g})$ at Barrow (36.5 \pm $3.7,27.2$ to $45.0, \mathrm{n}=110$ ), and Cemetery Beach $(35.9 \pm 4.7,24.6$ to $47.5, \mathrm{n}=33$ ) were similar; hatchlings at both locations were heavier than at Munda (31.1 \pm 3.6, 18.0 to $37.5, \mathrm{n}=124$ ) (Tables $4 \& 5$ ). 


\section{DISCUSSION}

Our results present the first baseline data on the breeding biology of flatback turtles in Western Australia derived from multiple years of standardized survey effort, providing information with which to detect potential impacts from the rapidly expanding resources industry in this region. Despite national protection afforded by the Environmental Protection of Biodiversity and Conservation (EPBC) Act (1999), the IUCN currently lists the flatback turtle Natator depressus, endemic to Australia, as 'Data Deficient' (IUCN 2010), and this paucity of information constrains national and state efforts to develop informed and effective monitoring and management of this species.

The Barrow and Munda rookeries are considered regionally substantial although smaller than other comparably-sized national rookeries, such as Cape Domett in northwestern Australia, which supports an estimated average of 3250 nesting females $\mathrm{yr}^{-1}$ (Whiting et al. 2008), and Crab Island in the Gulf of Carpentaria, estimated at $\sim 3000$ females $\mathrm{yr}^{-1}$ (Limpus et al. 1983, 1993, Sutherland \& Sutherland 2003). Currently unpublished modeled estimates for Barrow between 2005/06 and 2011/12 indicate 1512 nesting females $\mathrm{yr}^{-1}$ (95\% CI: 1430 to 1593). Estimates for the Munda rookery using more advanced techniques and over an 18 yr sampling period ending 2012 indicate 1861 nesting females $\mathrm{yr}^{-1}$ (95\% CI: 1005 to 1033; Chevron Australia 2012). Both these estimates are high and were consistent among seasons, reflecting healthy stocks at both locations.

Worthy of comment is the decrease in the mean number of animals encountered per night at all 3 rookeries since 2009/10. We attribute this to methodological changes implemented to minimize the impact of tagging on nesting success by allowing females to complete nesting prior to tagging, thus reducing the total number of females encountered on each survey night.

Mean remigration interval at Barrow (1.9 yr) was shorter than at other monitored rookeries in this study. It was also shorter than the intervals recorded at flatback rookeries in eastern Australia (Bundaberg coast: 2.7 yr, Limpus et al. 1984; Curtis Island: 2.9 yr, Limpus et al. 2006; Peak Island: 2.2 yr, Parmenter \& Limpus 1995; Woongarra Coast: 3.2 yr, Limpus et al. 2006). Only Greenhill Island (1.4 yr, Hope \& Smit, 1998) in the western Northern Territories has recorded a shorter remigration interval. Variation in remigration intervals may reflect the variable location of foraging grounds; when available these data may make a substantial contribution to our understanding of this behavior.

The difference in remigration intervals between island and mainland nesters may be an artifact of variable survey effort, where a number of remigrating turtles may have been missed, for example in seasons of high cyclonic activity, or it may reflect the location and characteristics of remote foraging grounds. Ongoing analysis of post-nesting satellite tracking data presently underway will shed additional light on processes driving initiation of reproductive migration and consequent variation in interannual abundance of females present at the rookery in each reproductive season (K. L. Pendoley et al. unpubl. data). These findings will support increased state and nationwide management efficacy (Gerodette \& Taylor 1999) via identification and delineation of remote habitats and incorporation of this information into legislation and the design of marine reserve areas (Pendoley et al. in press).

Mean internesting interval at Barrow was significantly longer than at Munda and Cemetery Beach, which were similar to those recorded for other flatback populations in Australia, e.g. Woongarra coast and Curtis Island (Limpus et al. 2006) and Greenhill Island (Hope \& Smit 1998). Previous studies on green and loggerhead turtles found the duration of internesting intervals were related to sea surface temperature (SST) in these areas (Sato et al. 1998, Hays et al. 2002). Indeed, Bureau of Meteorology (BOM) data indicate Munda and Cemetery Beach are subject to warmer SSTs due to their more northerly latitude (www.bom.gov.au/productsIDY00007.shtml). Recent trackings of internesting females from rookeries at Barrow, Munda and Cemetery Beach describe individual variation in internesting behaviors such as surfacing time, level of activity and distance travelled between success clutches that may influence the duration of the internesting interval (P. A. Whittock et al. unpubl.).

Further, preliminary and unpublished data regarding adult size at all 3 rookeries may reflect additional, variable behavioral characteristics specific to animals at each rookery that warrant further investigation. Data indicate that adults nesting at Barrow Island were larger than those of mainland rookies, which may reflect variation among sites in displacement distance to remote foraging and developmental grounds, or their characteristics. Alternatively, the larger size recorded at Barrow may be the result of unique foraging strategies such as low fidelity to a fixed foraging ground, with animals preferring to 'graze' along extensive depth contours (Pendoley et al. in press). 
Clutch depth at Munda was recorded at excavation and may explain why clutch depth at this location was shallower than other rookeries. Limited access to this beach due to annual cyclonic activity invariably meant nests were excavated later in the year and may have had altered beach profiles in comparison to that at time of nesting. Overall, mean clutch depth ranged between $65.9 \mathrm{~cm}$ at Munda to $71.1 \mathrm{~cm}$ at Barrow and was deeper than all other rookeries for which this value is reported (range of means: 49.9 to 65.0 cm: Limpus 1971, Limpus et al. 1983, Blamires \& Guinea 2003, Schäuble et al. 2006, Whiting et al. 2008). Deeper clutches may represent a regional adaptation to safeguard eggs threatened by the relatively high rates of erosion and accretion of sand due to cyclonic activity in Western Australia compared to other regions where flatbacks nest, or they may be indicative of adaptive evolutionary behavior developed as a means of temperature control.

Mean hatching success at Barrow was high $(83.4 \%)$ and comparable with the 70 to $90 \%$ recorded at other flatback turtle rookeries (Limpus 1971, Parmenter \& Limpus 1995, Blamires \& Guinea 2003, Schäuble et al. 2006; Whiting et al. 2008). However, hatching success rates at the 2 mainland rookeries, Cemetery Beach (57.3\%) and Munda (68.2\%), were the lowest recorded for any flatback rookery to date. Low success may be due to high temperatures during incubation at Munda $\left(33.1^{\circ} \mathrm{C}\right)$ and Cemetery Beach $\left(34.0^{\circ} \mathrm{C}\right)$, which fall just under the upper end of the thermal tolerance range (TTR) for other species of marine turtle $\left(33\right.$ to $35^{\circ} \mathrm{C}$, Ackerman 1997); this value has not yet been determined for this species and embryos of this species have been shown to survive in temperatures exceeding the reported TTR in studies conducted on the east coast of Australia (Hewavisenthi \& Parmenter 2002). Alternatively, storm surge-associated high cyclonic activity in this region may inundate clutches either briefly or over extended durations, halting embryonic development. This is supported by investigation of clutch temperature profiles in combination with rainfall and tide height data and in comparison to proximal sand temperature profiles (Pendoley Environmental unpubl.). Identifying causal factors driving high embryonic mortality at mainland beaches is a priority for future investigation. Clutch sizes were similar at all monitored rookeries (45 to 47 eggs), and were the smallest recorded for any flatback population, which typically average at least 50 eggs per clutch (Parmenter \& Limpus 1995, Sutherland \& Sutherland 2003, Hamann et al. 2006, Schäuble et al. 2006, Whiting et al. 2008).
These data make an invaluable contribution to ongoing and accurate assessment of demographic status and national management of this species. Future research should focus on further definition of key demographic parameters and detection of longterm trends. Elucidating drivers of variation in key facets of reproductive biology between mainland and island rookeries, understanding temperature tolerance and pivotal temperatures of flatback turtle embryos, and characterization of habitat use patterns and their implications for variations in reproductive biology and spatial ecology among turtles from the 3 rookeries are fundamental to expanding the current store of knowledge and developing meaningful response strategies for successful long-term management of the species.

Acknowledgements. Tagging was conducted under licenses from the Western Australian DPaW. Funding and logistical support for this study were provided by Chevron Australia and BHP Billiton Iron Ore, with special thanks to Keith Morris (DEC) and Russell Lagdon (Chevron Australia) for recognizing the value of the proposal at the outset, and Dorian Moro (Chevron Australia) and Sonja Mavrick (BHP Billiton Iron Ore) and Milani Chaloupka for ongoing support. Finally, none of this work would have been possible without the support of the hundreds of volunteers who gave up time each year to travel to Barrow Island and Mundabullangana Station to conduct the tagging program. We are grateful for the help of several anonymous reviewers for their input on early drafts of this manuscript and a further 3 anonymous reviewers on a more developed version of the manuscript.

\section{LITERATURE CITED}

Ackerman RA (1997) The nest environment and the embryonic development of sea turtles. In: Lutz PL, Musick JA (eds) The biology of sea turtles, Vol I. CRC Press, Boca Raton, FL, p 83-106

Blamires SJ, Guinea ML (2003) Emergence success of flatback sea turtles (Natator depressus) at Fog Bay, Northern Territory. Chelonian Conserv Biol 4:548-556

Bustard HR, Greenham P, Limpus C (1975) Nesting behavior of loggerhead and flatback turtles in Queensland, Australia. Proc Koninkl Nederl Akad van Wetenschappen C 78:111-122

Chevron Australia (2012) Gorgon gas development and Jansz feed gas pipeline: Ministerial Implementation Statement No. 800, Ministerial Implementation Statement No. 769, EPBC Reference: 2003/1294 (as amended) and EPBC Reference: 2008/4178 Environmental Performance Report 2012. www.chevron australia.com/Libraries/Chevron_Documents/Gorgon_ Project_Ministerial_Implementation_Statement_No_800_ and_No_769_EPBC_Reference_20031294_as_amended_ and_EPBC_Reference_20084178_Environmental_Perfor mance_2012.pdf.sflb.ashx]

DEC (Department of Environment and Conservation) (2007) Management plan for the Montebello/Barrow Islands Marine Conservation Reserves 2007-2017. Management 
Plan No 55, Marine Parks and Reserves Authority, Government of Western Australia, Perth

Dutton DL, Broderick D, Fitzsimmons NN (2002) Defining management units: molecular genetics. In: Kinan I (ed) Proc Western Pacific Sea Turtle Cooperative Research and Management Workshop, Honolulu, HI, 2-5 Feb 2002. Western Pacific Regional Fishery Management Council, Honolulu, HI, p 93-101

Gerodette T, Taylor BL (1999) Estimating population size. In: Eckert KL, Bjorndal KA, Abreu-Grobois FA, Donnelly M (eds) Research and management techniques for the conservation of sea turtles. IUCN/SSC Marine Turtle Specialist Group Publication No 4, IUCN, Washington, DC, p 67-71

Hamann M, Schauble C, Simon T, Johnson J, Evans S, Dorr T, Kennett R (2006) Sea turtles nesting in the Sir Edward Pellew Islands, Gulf of Carpentaria, Northern Territory. Mem Queensl Mus 52:71-78

> Hays GC, Broderick AC, Glen F, Godley BJ, Houghton JR, Metcalfe JD (2002) Water temperature and internesting intervals for loggerhead (Caretta caretta) and green (Chelonia mydas) sea turtles. J Therm Biol 27:429-432

Hewavisenthi S, Parmenter CJ (2002) Incubation environment and nest success of the flatback turtle (Natator depressus) from a natural nesting beach. Copeia 2002: 302-312

Hope R, Smit N (1998) Marine turtle monitoring in Gurig National Park and Coburg Marine Park. In: Kennett $\mathrm{R}_{\mathrm{r}}$ Webb A, Duff G, Guinea M, Hill G (eds) Marine turtle conservation and management in Northern Australia. Northern Territory University, Darwin, p 53-62

Ihaka R, Gentleman R (1996) R: a language for data analysis and graphics. J Comput Graph Stat 5:299-314

IUCN (International Union for the Conservation of Nature) (2010) IUCN Red List of threatened species. Version 2013.2. www.iucnredlist.org/

Limpus CJ (1971) The flatback turtle, Chelonia depressus (Garman) in southeast Queensland, Australia. Herpetologica 27:431-446

> Limpus CJ (1992) Estimation of tag loss in marine turtle research. Wildl Res 19:457-469

Limpus CJ (2009) A biological review of Australian marine turtles. Queensland Environmental Protection Agency, Brisbane

Limpus CJ, Parmenter CJ, Parker R, Ford N (1981) The flatback turtle Chelonia depressa in Queensland: the Peak Island rookery. Herpetofauna 13:14-18

Limpus CJ, Parmenter CJ, Baker V, Fleay A (1983) The Crab Island sea turtle rookery in the north-eastern Gulf of Carpentaria. Aust Wildl Res 10:173-184

Limpus CJ, Fleay A, Baker V (1984) The flatback turtle, Chelonia depressa, in Queensland: reproductive periodicity, philopatry and recruitment. Aust Wildl Res 11:579-587

Limpus CJ, Gyuris E, Miller JD (1988) Reassessment of the taxonomic status of the sea turtle genus Natator McCulloch 1908, with a redescription of the genus and species. Trans R Soc S Austr 112:1-9

Editorial responsibility: Matthew Godfrey, Beaufort, North Carolina, USA
Limpus CJ, Couper PJ, Couper KD (1993) Crab Island revisited: reassessment of the world's largest flatback turtle rookery after twelve years. Mem Queensl Mus 33: 277-289

Limpus CJ, McLaren M, McLaren G, Knuckey B (2006) Queensland Turtle Conservation Project: Curtis Island and Woongarra Coast flatback turtle studies, 20052006. Queensland Environmental Protection Agency, Brisbane

Miller JD (1999) Determining clutch size and hatching success. In: Eckert KL, Bjorndal KA, Abreu-Grobois FA, Donnelly M (eds) Research and management techniques for the conservation of sea turtles. IUCN/SSC Marine Turtle Specialist Group Publication No 4, IUCN, Washington, DC, p 124-129

Parmenter CJ (1993) A preliminary evaluation of the performance of passive integrated transponders and metal tags in a population study of the flatback sea turtle (Natator depressus). Wildl Res 20:375-381

Parmenter CJ, Limpus CJ (1995) Female recruitment, reproductive longevity and inferred hatchling survivorship for the flatback turtle (Natator depressus) at a major eastern Australian rookery. Copeia 1995:474-477

Pendoley KL (2005) Sea turtles and the environmental management of industrial activities in north west Western Australia. Doctoral dissertation, Murdoch University, Perth

Pendoley KL, Schofield G, Whittock PA, Ierodiaconou D, Hays G (in press) Multi-species use of a coastal migratory corridor connecting Marine Protected Areas. Mar Biol

Sato K, Matsuzawa Y, Tanaka H, Bando T, Minamikawa S, Sakamato W, Naito Y (1998) Internesting intervals for loggerhead turtles, Caretta caretta, and green turtles, Chelonia mydas, are affected by temperature. Can J Zool 76:1651-1662

Schäuble C, Kennett R, Winderlich S (2006) Flatback turtle (Natator depressus) nesting at Field Island, Kakadu National Park, Northern Territory, Australia 1990-2001. Chelonian Conserv Biol 5:188-194

Shigenaka G (2003) Oil and sea turtles: biology, planning and response. National Ocenaic and Atmospheric Administration, US Dept of Commerce, Washington, DC

Sutherland RW, Sutherland EG (2003) Status of the flatback turtle (Natator depressus) rookery on Crab Island, Australia, with notes on predation by crocodiles. Chelonian Conserv Biol 4:612-619

Wallace BP, DiMatteo AD, Hurley BJ, Finkbeiner EM, Bolten AB (2010) Regional management units for marine turtles: a novel framework for prioritizing conservation and research across multiple scales. PLoS ONE 5: e15465

Whiting AU, Thomsoni A, Chaloupka M, Limpus CJ (2008) Seasonality, abundance and breeding biology of one of the largest populations of nesting flatback turtles, Natator depressus: Cape Domett, Western Australia. Aust J Zool 56:297-303

Submitted: June 26, 2013; Accepted: November 12, 2013 Proofs received from author(s): January 31, 2014 